\title{
Climate change and agricultural adaptation in Sri Lanka: a review
}

Article

Accepted Version

Confirmed with author - final author version

Esham, M. and Garforth, C. (2013) Climate change and agricultural adaptation in Sri Lanka: a review. Climate and Development, 5 (1). pp. 66-76. ISSN 1756-5537 doi: https://doi.org/10.1080/17565529.2012.762333 Available at https://centaur.reading.ac.uk/30166/

It is advisable to refer to the publisher's version if you intend to cite from the work. See Guidance on citing.

To link to this article DOI: http://dx.doi.org/10.1080/17565529.2012.762333

Publisher: Taylor and Francis

All outputs in CentAUR are protected by Intellectual Property Rights law, including copyright law. Copyright and IPR is retained by the creators or other copyright holders. Terms and conditions for use of this material are defined in the End User Agreement.

\section{www.reading.ac.uk/centaur}

\section{CentAUR}

Central Archive at the University of Reading

Reading's research outputs online 


\section{climate and development}

\section{Climate change and agricultural adaptation in Sri Lanka: a review}

\begin{tabular}{|r|l|}
\hline Journal: & Climate and Development \\
\hline Manuscript ID: & 12-CDEV075-RV.R4 \\
\hline Manuscript Type: & Review Article \\
\hline Keywords: & $\begin{array}{l}\text { Agriculture, Adaptation, Climate Change, Impacts of climate change, Sri } \\
\text { Lanka }\end{array}$ \\
\hline \multicolumn{2}{|r}{} \\
\hline
\end{tabular}

SCHOLARONE

Manuscripts 


\title{
Climate change and agricultural adaptation in Sri Lanka: a review
}

\begin{abstract}
Climate change is inevitable and will continue into the next century. Since the agricultural sector in Sri Lanka is one of the most vulnerable to climate change, a thorough understanding of climate transition is critical for formulating effective adaptation strategies. This paper provides an overview of the status of climate change and adaptation in the agricultural sector in Sri Lanka. The review clearly indicates that climate change is taking place in Sri Lanka in terms of rainfall variability and an increase in climate extremes and warming. A number of planned and reactive adaptation responses stemming from policy and farm-level decisions are reported. These adaptation efforts were fragmented and lacked a coherent connection to the national development policies and strategies. Research efforts are needed to develop and identify adaptation approaches and practices that are feasible for smallholder farmers, particularly in the dry zone where paddy and other food crops are predominately cultivated. To achieve the envisaged growth in the agricultural sector, rigorous efforts are necessary to mainstream climate change adaptation into national development policies and ensure that they are implemented at national, regional and local levels.
\end{abstract}

Keywords: adaptation; agricultural sector; climate change; climate change impacts; Sri Lanka

\section{Introduction}

There is increasing evidence that global climate change is taking place. It is being experienced in various forms including as temperature rise, sea level rise, droughts, floods, hurricanes and landslides. According to the Fourth Assessment Report of the 
Intergovernmental Panel on Climate Change (IPCC), even with immediate implementation of mitigation strategies, global climate change will continue for decades (IPCC, 2007a). Climate change is inflicting serious consequences on human wellbeing and will continue to inflict damages in the future. By the end of the $21^{\text {st }}$ century, the mean global temperature is projected to rise by $1.8^{\circ} \mathrm{C}-4.0^{\circ} \mathrm{C}$ (Izaurraade, 2009). Climate change has developed into an issue of utmost concern prompting IPCC (2007b) to strongly recommend measures to mitigate and adapt to climate change.

Most profound and direct impacts of climate change over the next few decades will be felt on agricultural and food systems (Brown and Funk, 2008). Although, at present, the overall impact of climate change on the global scale agricultural productivity is not reliably estimated (Gornall et al., 2010), many studies show serious implications for agricultural productivity. For instance, Nelson et al. (2009) projects that in South Asia by 2050, climate change will reduce production of rice, wheat and maize by $14 \%, 44 \%$ to $49 \%$ and $9 \%$ to $19 \%$ respectively relative to a no climate change situation. Historical temperature-yield relationship indicates that, at the global scale, warming from 1981-2002 possibly offset some of the yield gains from technology advances, rising $\mathrm{CO}_{2}$ and other non-climatic factors (Lobell and Field, 2007).

Most serious impacts of global climate change will be felt on smallholder farmers in the developing countries. Their vulnerability to climate change comes from being predominately located in the tropics, high dependence on natural resources, small farm sizes, low technology and capitalization, poor infrastructure and institutional support limiting their capacity to adapt to change (Morton, 2007; Conway, 2008; World Bank, 2008). Vulnerability to climate change is the propensity of human and ecological systems to suffer harm from exposure to stresses associated with climate change and from the absence of capacity to adapt (Adger, 2006; Adger et al., 2007). 
Adaptation to climate change refers to adjustment in natural or human systems in response to actual or expected climatic stimuli in order to ameliorate negative effects and take advantage of opportunities associated with climate change (IPCC 2007b). Climate change adaptation simply means reducing the vulnerability of people's lives and livelihoods to risk posed by climate change.

In Sri Lanka, about $71 \%$ of agricultural land holdings are less than one hectare (Department of Census and Statistics, 2004), while 66\% of cropland is rain-fed (Biradar et al., 2009) and therefore increasingly vulnerable to impacts of climate variability and extremes. In 2009, agricultural sector growth was stifled by the impact of drought and delayed monsoon rains on the production of two principal crops paddy and tea (Central Bank of Sri Lanka, 2010).

The need for adaptation strategies that are feasible in communities to minimize climate change impacts is seen as a necessity and no longer deniable. Available studies (Wijeratne, 1996; Droogers, 2004; De Silva et al., 2007) show that climate change impacts on the agricultural sector in Sri Lanka can be significantly reduced through appropriate adaptation strategies (see discussion in section 4).

Given the importance of climate change impacts on local agriculture and food security, this paper aims to improve the understanding of climate change and its implications for the agricultural sector in Sri Lanka by providing an overview of observed and projected climate change and reviewing recent literature related to climate change impacts on agriculture and agricultural adaptation. This paper also attempts to identify key knowledge gaps and future research needs in climate change and agriculture in Sri Lanka.

The remainder of this paper will be organized as follows: the second section will cover agriculture and climate change. The third section will review literature on impacts of climate 
change on the agricultural sector and the fourth section will deal with agricultural adaptation to climate change. Finally, the fifth section will contain the conclusions.

\section{Agriculture and climate change}

\subsection{Agriculture and climate in Sri Lanka}

Sri Lanka is an island nation located under the Indian peninsula with an area of 65,610 sq. $\mathrm{km}$. The country has a population of 20.5 million with a per capita GDP of US\$ 2,400 . The majority of the population (70\%) lives in rural areas where farming is widely practiced. Almost one tenth of the population lives below the poverty line (Central Bank of Sri Lanka, 2011). Agriculture continues to be one of the key sectors contributing to the national economy. In 2009, the agricultural sector contributed 12\% to GDP (Central Bank of Sri Lanka, 2010). Although the contribution of agriculture is now only around one tenth of GDP, it plays a vital role in the country's economic development because it is the main source of livelihood for rural Sri Lankans.

The agricultural sector of Sri Lanka is dualistic, comprising plantation and non-plantation agriculture. Plantation agriculture is export oriented and mainly involves the production of tea, rubber and coconut, while non-plantation agriculture is concerned with the production of food crops such as paddy, other cereals, pulses, condiments, vegetables and fruits, mainly for domestic consumption (Esham et al., 2005).

The national development strategy known as Mahinda Chintanaya considers agriculture as a cornerstone and envisages a 4\% to 5\% annual growth during 2006-2016, while the sectoral plan for agriculture emphasises the achievement of food security and enhancing the incomes of smallholder farmers. 
Based on ecological parameters such as rainfall, soil type and topography, Sri Lanka is divided into three principal agro-climatic zones namely, wet zone, intermediate zone and dry zone (Panabokke, 1996). Out of the total land area of 6.56 million ha, the bulk of land area or 4.17 million ha belongs to the dry zone, 1.54 million ha to the wet zone and the remaining 0.85 million ha to the intermediate zone (Kudagamage, 1998). The three agro-climatic zones (Figure 1) are divided into seven agro-ecological regions based on altitude.

\section{Figure 1 About here}

In Sri Lanka, the climatic parameter that has the greatest impact on agriculture is rainfall. The rainfall climate of Sri Lanka can be characterized as a tropical monsoon climate. Two distinct monsoon rainfall seasons and two inter-monsoon rainfall seasons can be recognized. The two main monsoon seasons are south-west monsoon (SWM) from May to September and north-east monsoon (NEM) from December to February. The first inter-monsoon (FIM) season runs from March to April and the second inter-monsoon (SIM) season from October to November (Ranatunge et al., 2003). The rainfall pattern leads to two distinct cropping seasons: the October to December rainfall coincides with the commencement of the main cultivation season known as maha (October-March), while the April to June rainfall coincides with the commencement of the subsidiary cultivation season known as yala (AprilSeptember) (Zubair, 2002).

\subsection{Climate change}

\subsubsection{Observed climate change}


Surface air temperature and precipitation are two key climatic variables that influence the agricultural sector in South Asia. Past and present climate trends and variability in South Asia are characterised by increasing surface air temperature. The analysis of seasonal and annual surface air temperatures for a number of locations in South Asia has revealed a significant warming trend of $0.7{ }^{\circ} \mathrm{C}$ per century (Lal, 2003). During recent decades, the observed increases in some parts of South Asia such as India, Bangladesh, Nepal, Pakistan and Sri Lanka have ranged between $0.07-1^{\circ} \mathrm{C}$ per decade (Cruz et al., 2007). Although some parts of South Asia recorded increasing and decreasing trends in the seasonal rainfall, in general, the rainfall fluctuations in South Asia have been largely random over the years, with no clear trend in the rainfall pattern (Cruz et al., 2007).

A number of studies have shown significant systematic warming in Sri Lanka over the past few decades. Annual mean surface air temperature anomalies over Sri Lanka during the period 1869-1993 suggest a conspicuous and gradual increase of about $0.30{ }^{\circ} \mathrm{C}$ per 100 years (Rupakumar and Patil, 1996). Mean surface temperature has increased during a 30-year period (1961 to 1990$)$ at a rate of $0.016{ }^{\circ} \mathrm{C}$ per year (Chandrapala, 1996). Analysis of longterm air temperature data shows that significant warming has taken place in all climatic zones, while most locations exceed the global average rate of warming (De Costa, 2008). The rate of warming has accelerated in recent years: during the 1987-1996 period temperature increased by $0.025^{\circ} \mathrm{C}$ per year (Fernando et al., 2007; Zubair et al., 2010).

Precipitation is another key climatic parameter influencing agriculture. Both the quantity of rainfall and the variability are crucial for agricultural production. Effects of precipitation relative to temperature are more important for agriculture in a tropical country like Sri Lanka (Kurukulasuriya and Ajwad, 2007). Despite the absence of statistically conclusive evidence, both variability and amount of rainfall have changed over time. A downward trend in rainfall can be seen as the annual average rainfall during 1931-1960 estimated at $2005 \mathrm{~mm}$, declined 
to 1861 mm during 1961-1990 (Chandrapala 1996; Domroes 1996; Domroes and Schaefer, 2000; Jayatillake 2005). Reduction in rainfall is noticeable from the NEM and the SIM (Imbulana et al., 2006). Both the rainfall and number of rainy days have declined in the upcountry region (Herath and Ratnayake, 2004). Data from 1869 to 2006 show a declining rainfall trend in the higher elevations (up-country) from the SWM (De Silva and Sonnardara, 2009).

\section{Figure 2 About here}

Rainfall variability is critical for crop cultivation as the principal cropping seasons follow the rainfall pattern. Studies have shown that intra-seasonal rainfall variability is a significant aspect of the rainfall climatology of Sri Lanka (Malmgren et al., 2003). In Sri Lanka, variability of seasonal rainfall has increased making predictability of rainfall difficult (Punyawardena, 2008). In recent years, rainfall variability accompanied by climate extremes has become a norm rather than an exception in the dry zone (Panabokke and Punyawardena, 2010). High rainfall variability induces extreme rainfall events such as floods and droughts, which are the most prominent climate based natural disasters inflicting damages to agriculture in Sri Lanka. As shown in Figure 2, frequency of occurrence of both droughts and floods are showing an increasing trend over the years. However, despite this increasing trend, cereal production in the country increased by five folds over the past five decades as a result of the green revolution and subsequent technology advances in agriculture.

The El Niño-Southern Oscillation (ENSO) contributes largely to climate variability in the South Asian region and exhibits a strong relationship with the Sri Lankan rainfall pattern (Suppiah, 1997; Zubair et al., 2002; Zubair and Ropelewski, 2006; Zubair et al., 2008; Goddard et al., 2010). El Niño normally leads to wetter conditions during October to 
December and drier conditions during January to March and July to August (Zubair et al., 2008). In recent years, the positive relationship between ENSO and NEM rainfall has strengthened (Kumar et al., 2007). This has resulted in above normal NEM rainfall and the prevalence of floods during November to December period. Studies by Chandrapala (1996), Domroes (1996) and Ranatunga et al. (2003) point to a declining trend of SWM rainfall over the south-western part of Sri Lanka.

\subsubsection{Projections of climate change in Sri Lanka}

Temperature: The IPCC predicts that South Asia will experience warming above the global average. By the end of the 21 st century, the mean temperature in South Asia is projected to increase by $3.3^{\circ} \mathrm{C}$ (IPCC, 2007a). There are a few temperature projections for Sri Lanka with varying outcomes. According to Basnayake (2011), temperature in Sri Lanka is predicted to increase by $2.4^{\circ} \mathrm{C}$ by the end of the century. Downscaled projections of HadCM3 (Hadley Centre Coupled Model, version 3) for Special Report on Emissions Scenarios(SRES) A1 and B2 reveals that temperature by 2050 will increase by $1.6^{\circ} \mathrm{C}$ under $\mathrm{A} 2$ and $1.2^{\circ} \mathrm{C}$ under $\mathrm{B} 2$ (De Silva, 2006). According to Basnayake et al. (2004), HadCM3 model projects higher temperature increments (about $2.7{ }^{\circ} \mathrm{C}$ by 2100 under A1FI) while GCM (General Circulation Models) project lower temperature increments (about $2.0^{\circ} \mathrm{C}$ by 2100 under A1FI). Predictions using five GCMs show that May temperature by 2100 will increase within the range of $1.58^{\circ} \mathrm{C}$ to $3.41^{\circ} \mathrm{C}$ (Seo et al., 2005). Another, GCM based study projects that, by the end of the $21^{\text {st }}$ century, annual average temperature in the country would increase by $2.84^{\circ} \mathrm{C}$ (Cline, 2007). According to projections by Basnayake (2011), by the end of the century, the mean temperature during the NEM and SWM is to increase by about $2.9^{\circ} \mathrm{C}$ and $2.5^{\circ} \mathrm{C}$ respectively. As far as agricultural production is concerned, not only the mean temperature increase but also the variations in minimum and maximum temperature also become significant. It is 
predicted that, by 2050 , minimum and maximum mean temperatures will increase between the ranges of $0.5^{\circ} \mathrm{C}$ to $0.7^{\circ} \mathrm{C}$ and $0.6^{\circ} \mathrm{C}$ to $0.9^{\circ} \mathrm{C}$ respectively (Jayatillake and Droogers, 2004). Given these predictions, the consensus is that the warming trend will continue into the future.

Rainfall: Climate models indicate an increase in annual rainfall in most of Asia during this century, while the summer monsoon is projected to produce more rainfall over South Asia (Cruz et al., 2007). Majority of available studies on rainfall projection for Sri Lanka for the $21^{\text {st }}$ century show an increasing trend in mean annual rainfall (De Silva, 2006; Cline, 2007; Cruz et al., 2007; De Silva et al., 2007), while a few studies indicate a declining trend (Basnayake et al., 2004; Ashfaq et al., 2009). Compared to the period 1961-1990, by 2050, the mean annual average rainfall will increase under A2 and B2 SRES scenarios by $14 \%$ and 5\% respectively (De Silva et al., 2007). According to Cline (2007), a marginal increase (106 $\mathrm{mm}$ ) in annual rainfall is projected for the period 2070-2099 relative to the base period of 1961-1990. However, wide spatial and temporal variations will be observed as rainfall from the SWM will increase and the NEM rainfall will decline, while some dry zone areas will receive reduced rainfall and some districts in the wet zone will receive more rain (De Silva, 2006; De Silva et al., 2007). It is estimated that, by 2050 , rainfall will decrease by $9 \%$ to $17 \%$ in the main maha cultivation season, which coincides with the NEM (De Silva et al., 2007). In South Asia, most of the AR4 models project a decrease in precipitation in December, January and February (Cruz et al., 2007). A few studies indicate a decreasing trend in mean annual rainfall. A downscaled GCM projects both SWM and NEM to provide less rainfall (Basnayake et al., 2004). A study by Ashfaq et al. (2009) evidenced an increased occurrence of break spells, delayed monsoon onset and weaker cross-equatorial monsoonal winds leading to lower monsoon precipitation. The literature on rainfall projections demonstrates 
the need to undertake studies based on regional climate models to obtain more accurate projections for the country. The consensus is that there will be substantial changes in rainfall patterns to which farmers will have to adapt.

\section{Impact of climate change on agriculture}

Agriculture, as one of the most climate dependent human activities will be severely affected by climate change. Climate change will affect the agricultural sector in Sri Lanka mainly due to the variability in rainfall, increase in temperature and elevated $\mathrm{CO}_{2}$ concentration. Recent global estimates predict that, by 2080 , climate change will reduce world agricultural production capacity as much as by $16 \%$ if $\mathrm{CO}_{2}$ fertilization effect is omitted and by $3 \%$ if it is included. As far as Sri Lanka is concerned, the reduction is projected to be more severe, with production losses of up to $20 \%$ (Cline, 2007).

The main crops cultivated in Sri Lanka such as paddy, tea and coconut are highly sensitive to variations in temperature and precipitation (Wijeratne and Fordham, 1996; Fernando, 2000; Peiris et al., 2004). Climate change will equally affect both plantation and nonplantation agriculture. However, the implications of climate change will be more severe on the non-plantation agriculture because the majority of farmers are smallholders and predominantly cultivate paddy. Paddy is a crop that requires a large quantity of irrigation water and at the same time, these farmers exhibit a marked reluctance to diversify away from paddy due to cultural affinity of the crop to their livelihoods (Esham and Garforth, 2012).

Increasing nighttime mean temperature has a significant impact on rice yield (Peng et al., 2004; Nagarajan et al., 2010; Welch et al., 2010). paddy yield declined by $10 \%$ for each $1{ }^{\circ} \mathrm{C}$ increase in growing-season minimum temperature in the dry season at the IRRI farm (Peng et al., 2004). Although there are positive effects of elevated $\mathrm{CO}_{2}$ on crop yields (De Costa et al., 
2003; Kimball et al., 2002; Ainsworth and Long, 2005) and significant yield increases in paddy, even when grown in warm sub-humid tropical climates (De Costa et al., 2003), results from Free Air Carbon Enrichment (FACE) experiments cast doubts on whether $\mathrm{CO}_{2}$ fertilisation will fully compensate for yield losses resulting from increased temperature under climate change (Kimball et al., 2002; Long et al., 2006). A meta-analysis shows that elevated $\mathrm{CO}_{2}$ will increase rice yield but this will be negated by rising temperature and $\mathrm{O}_{3}$ (Ainsworth, 2008). Studies in Sri Lanka too have shown that yield gains from elevated $\mathrm{CO}_{2}$ are almost negated by temperature increases (De Costa, 2000).

Rainfall reduction and increased variability will not only affect the crop productivity but also disturb the cropping calendar. Shorter cultivation seasons due to the delayed onset of monsoon are a common occurrence in Sri Lanka (Silva, 2008; Senadilankara and Manawadu, 2010). Some studies have been undertaken to understand the impact of rainfall variability on crop productivity. A study on the impact of rainfall variability attributed to ENSO phenomenon on rice production has revealed that during the El Niño phase, the maha rice production frequently increased and the yala production frequently decreased, while during the La Niña phase, the maha production decreased and the yala production increased (Zubair, 2002). It is predicted that by 2050 , the majority of paddy growing areas will receive less rainfall in the maha season and as a result paddy cultivation in Sri Lanka will become water stressed (De Silva et al., 2007).

Coconut production too shows sensitivity to rainfall and to dry spells in the growing regions (Peiris et al., 2008). Peiris et al. (2004) confirmed that changes in monsoon rainfall pattern and increase in maximum air temperature as two key factors influencing the variability of coconut production in the principal coconut growing regions. Projected coconut production after 2040 in all climate scenarios, when other external factors are non-limiting, will not be sufficient to cater for the local demand (Peiris et al., 2004). It is estimated that 
between US\$ 32 million to 73 million is lost due to low precipitation, while high rainfall results in an economic gain between US\$ $42-87$ million (Fernando et al., 2007). Decline in rainfall will have serious consequences on the tea sector as a reduction of monthly rainfall by $100 \mathrm{~mm}$ could reduce productivity by $30-80 \mathrm{~kg} / \mathrm{ha} / \mathrm{month}$ of made tea (Wijeratne et al., 2007).

As the majority of smallholder farmers in Sri Lanka are dependent on rain for their irrigation needs, they are most vulnerable to variability and reduction of precipitation since it has implications for farm profitability (Kurukulasuriya and Ajwad, 2007). Some studies have estimated the economic loss from climate change impacts on Sri Lankan agriculture. Ricardian econometric estimates based on temperature and precipitation projections made with GCMs indicate that impacts of rainfall increases are predicted to be beneficial to the country as a whole; however, temperature increases are predicted to be harmful. Based on GCM climate predications for Sri Lanka by 2100 , nationally, the impacts on agricultural production (paddy, tea, rubber and coconut) will vary from -11 billion rupees ( -20 per cent) to +39 billion rupees ( +72 per cent) depending on the climate scenarios (Seo et al., 2005). With a mild warming and a large increase in precipitation, a gain of net revenue of $22 \%$ and medium warming and only a small increase in precipitation, a loss of $23 \%$ of net revenue is predicted. These impacts are likely to vary considerably across geographic areas, with the largest adverse impacts anticipated in the dry zones of the north-central region and the dry zones of the south-eastern regions of Sri Lanka (Kurukulasuriya and Ajwad, 2007).

Evidence shows a strong correlation between climatic conditions and national agricultural growth. A phenomenal annual growth rate of $7.5 \%$ was possible in 2008 due to conducive climatic conditions; however, the growth rate declined to $1.5 \%$ in 2011 due to adverse climatic conditions (Central Bank of Sri Lanka, 2009, 2011). In this context, it will not be possible to maintain the envisaged annual target growth rate at $5 \%$ as spelled out in the 
national development strategy unless feasible adaptation measures are promoted, particularly among the smallholder farmers.

\section{Agricultural adaptation to climate change}

Although there are ambiguities in the distinction between types of adaptation, i.e. how adaptation occurs (Eisenack and Stecker, 2011), literature identifies different types of adaptation such as anticipatory, reactive, planned and autonomous (Smith, 1997; Fankhauser et al., 1999; Tol, 2005). Reactive adaptations are measures taken in response to climate change impacts, while anticipatory adaptation measures are taken in advance of climate change (Smith, 1997). Autonomous adaptation refers to adaptation decisions that are not made by government agencies; these decisions are made by private firms and households in order to adjust to the realities of climate change, while planned adaptation refers to decisions that are made by government bodies (Stage, 2010). According to Smit and Skinner (2002), agricultural adaptation options are grouped into four main categories: (1) technological developments, (2) government programs and insurance, (3) farm production practices and (4) farm financial management. Categories 1 and 2 principally involve policy level decisions by government agencies while categories 3 and 4 mainly involve farm-level decision-making by producers. In this paper, Smit and Skinner`s (2002) typology is used to examine agricultural adaptation efforts in Sri Lanka. Some adaptation efforts reported in the literature are summarized in Table 1.

\section{Table 1 About here}

The government of Sri Lanka realising the importance of climate change adaptation, has taken several initiatives at the policy level to address the concerns of climate change. 
However, it is significant to note that neither the national development strategy nor the national agricultural policy had addressed the issue of climate change explicitly. This implies that little effort has been made to mainstream climate change adaptation into national development policies until the National Climate Change Adaptation Strategy(NCCAS) was formulated in 2010, where the importance of mainstreaming climate change adaptation into national planning and development is highlighted. The NCCAS is structured into five strategic thrust areas of which the third is focused on minimizing climate change impacts on food security (Ministry of Environment, 2010). The success of NCCAS will depend largely on resource availability and the institutional setup established to operationalize adaptation strategies at different scales such as national, regional and local. Sri Lanka ratified the UNFCC in 1993 and the Kyoto Protocol in 2002, thereby affirming its commitments to the UNFCC. The initial communication drafted for the UNFCCC in 2000 spells out a number of adaptation strategies for the agricultural sector under five areas: productivity, cropping systems, water management, land use and awareness. However, there is no evidence to indicate that any of the proposed measures are being implemented as planned adaptations. In 2005, a national rainwater harvesting policy was formulated to promote rainwater harvesting in the dry zone areas to adapt to anticipated decline in rainfall (Ministry of Urban Development and Water Supply, 2005).

On the technology development front, the most common approach is to develop crop varieties to increase tolerance to moisture stress, salinity, high temperature and elevated $\mathrm{CO}_{2}$ levels. Short duration rice varieties suitable for short growing seasons have been developed and field-tested (Harris and Satheeswaran, 2005). Rice varieties suitable for high $\mathrm{CO}_{2}$ concentration have been identified from the Sri Lankan rice germplasm pool (De Costa et al., 2007). Aerobic rice varieties requiring less water are found to suit tropical conditions similar to Sri Lanka (Bouman et al., 2005). Research studies are carried out to identify drought 
tolerant coconut varieties at the Coconut Research Institute (Nainanayake and Morison, 2007). An innovative participatory research approach was successfully used to identify salt resistant traditional rice varieties in the Hambantotta district. This approach enabled farmers to assess threats to their livelihoods and develop their own responses with the support of the strong stakeholder network developed by the facilitating NGO (Berger et al., 2009). Stakeholder participation, coordination and climate change awareness raising were critical success factors of this initiative (Sterrett, 2011).

Some studies (Senaratne and Wickramasinghe, 2010; Esham and Garforth, 2012) have identified local level adaptations. According to Senaratne and Wickramasinghe (2010), the village tank based farming communities in the dry zone adapt by aligning farming activities with the recognized seasonal pattern of rainfall and managing rainwater harvested in the commonly owned village tanks. Crop management that includes practices such as change in planting dates, shortening of the growing season, changing crop varieties and crop rotation is the most prevalent adaptation practice among farmers in the intermediate zone (Esham and Garforth, 2012). Crop management practices such as system of rice intensification (SRI) are considered effective in conserving water in paddy cultivation (Somartne, 2010). Paddy cultivation in the dry and intermediate zones in Sri Lanka under zero tillage condition has enabled a reduction in cost of production and enhanced conservation of water without significantly affecting the yield (Jayewardene et al., 2010). It should be noted that adaptation, particularly local level adaptation is taking place on farmers' own initiative in the absence of external support (Esham and Garforth, 2012). These adaptation efforts are motivated by many factors other than climate change, for example, income diversification through seeking offfarm employment is a result of increase in rural wages and not necessarily a climate adaptation strategy (Sumanaratne, 2011). 
Research studies in Sri Lanka have recommended various farm management methods to minimize the impact from climate change. Changing planting time to suit rainfall variability (De Silva et al., 2007), introduction of micro irrigation (Aheeyar et al., 2005) and reduction of irrigation depth (Droogers, 2004) are some of the proposed methods. For the tea sector, strategies such as use of hardy tea clones resistant to drought, pest and diseases, soil conservation techniques, shade management and multi-cropping systems are proposed (Wijeratne, 1996).

Similar to Sri Lanka, adaptation efforts in other South Asian countries too are fragmented and lack a strong link between national climate change strategies and plans and existing disaster risk reduction, agricultural and other development policies (Sterrett, 2011). Some of the characteristic features of effective adaptation efforts of these countries include: community participation, use of indigenous knowledge and practices, development of local technologies, stakeholder networking and combination of conventional technological innovation process with the tacit knowledge of farmers (Manadhar et al., 2011; Sterrett, 2011; Anik and Khan, 2012; Chhetri et al., 2012; Halder et al., 2012).

\section{Conclusions}

The review clearly indicates that climate change is taking place in Sri Lanka in terms of rainfall variability and an increase in climate extremes and warming. The climate projections indicate a further warming trend, while rainfall trends are not clear as studies show contradictory results. However, rainfall variability is projected to become more pronounced in the future making some areas drier in the years to come. This calls for urgent adaptation efforts particularly in the dry zone where predominately paddy and other food crops are cultivated. Research efforts are needed to develop and identify adaptation approaches and 
practices that are feasible for farmers in the dry zone, in particular, attention is needed with regard to the paddy crop due to its importance for food security and inherent vulnerability to risks stemming from climate change.

Review of the literature pointed to a number of planned and reactive adaptation efforts stemming from policy and farm-level decisions. In addition to these adaptation practices, there may be a number of other effective adaptation practices not yet reported in the literature. It is therefore important to examine these efforts to identify best practices with potential for replication and up-scaling.

Mostly local level adaptation is taking place on farmers' own initiative in the absence of external support from government agencies or donor agencies. Climate change will exacerbate the severity of impacts in the future, requiring farmers to contemplate action beyond the autonomous adaptation measures practiced at present. Hence, it is necessary for farming communities to adjust to new environments that are likely to evolve in the future. This will require the intervention of the state and other facilitating agencies to organize vulnerable communities to respond to climate change.

Although Sri Lanka long ago acknowledged the importance of climate change adaptation by being among the first few countries to ratify the UNFCC, our review shows that very slow progress has been made in implementing adaptation measures proposed at the policy level. The adaptation efforts identified in this paper are fragmented and lack coherent connections to the national development policies and strategies. It is also significant to note that neither the national development strategy nor the national agricultural policy have addressed the issue of climate change explicitly. This implies that little effort has been made to mainstream climate change adaptation into national development policies. Therefore, in light of the evolving climate change impacts, to achieve the envisaged growth in the agricultural sector rigorous efforts are necessary to mainstream climate change adaptation into national 
development policies and ensure that they are implemented at national, regional and local levels. The NCCAS launched in 2010 can form the basis for mainstreaming and implementing climate change adaptation if rigorous efforts are made at the policy level to make it work on the ground. An integrated and collaborative approach involving state, private sector, civil society and farmer based organizations is essential for the successful implementation of the NCCAS.

\section{Acknowledgement}

The authors gratefully acknowledge the Commonwealth Scholarship Commission for providing a fellowship to the first author for postdoctoral research at University of Reading, UK.

\section{References}

Adger, W.N., 2006. Vulnerability. Global Environmental Change, 16 (3). 268-281. DOI:10.1016/j.gloenvcha.2006.02.006.

Adger, W.N., S. Agrawala, M.M.Q. Mirza, C. Conde, K. O’Brien, J. Pulhin, R. Pulwarty, B. Smit and K. Takahashi, 2007: Assessment of adaptation practices, options, constraints and capacity. Climate Change 2007: Impacts, Adaptation and Vulnerability. Contribution of Working Group II to the Fourth Assessment Report of the Intergovernmental Panel on Climate Change, M.L. Parry, O.F. Canziani, J.P. Palutikof, P.J. van der Linden and C.E. Hanson, Eds., Cambridge University Press, Cambridge, UK, 717-743. 
Aheeyar, M. M. M., Kumara, S. K. and Samarasinha, G. G. de L. W., 2005. The Application of Micro Irrigation Technologies in the Small Farming Sector in Sri Lanka. HARTI, Colombo, Sri Lanka.

Aheeyar, M. M. M., 2010. Adaptation for water scarcity: rainwater-harvesting experience from Sri Lanka. Paper for the 2010 International Climate Change Adaptation Conference, 29 June- 1 July 2010, Australia.

Ainsworth, E. A. and Long, S. P., 2005. What have we learned from 15 years of free air $\mathrm{CO}_{2}$ enrichment (FACE)? A meta-analytic review of the responses of photosynthesis, canopy properties and plant production to rising $\mathrm{CO}_{2}$. New Phytologist, 165. 351-372.

Ainsworth, E. A., 2008. Rice production in a changing climate: a meta-analysis of responses to elevated carbon dioxide and elevated ozone concentration. Global Change Biology, 14. 1642-1650. DOI: 10.1111/j.1365-2486.2008.01594.x.

Anik, S. and Khan, M., 2012. Climate change adaptation through local knowledge in the north eastern region of Bangladesh. Mitigation and Adaptation Strategies for Global Change (in press). DOI:10.1007/s11027-011-9350-6.

Ashfaq, M., Shi, Y., Tung, W.W., Trapp, R.J., Gao, X., Pal, J.S. and Diffenbaugh, N.S., 2009. Suppression of South Asian summer monsoon precipitation in the 21st century. Geophysical Research Letters, 36. L01704. DOI:10.1029/2008GL036500. 
Basnayake, B. R. S. B., Rathnasiri J. and Vithanage J. C., 2004. Rainfall and temperature scenarios for Sri Lanka under the anticipated climate change, Paper for the 2nd AIACC Regional Workshop for Asia and the Pacific, Manila, Philippines.

Basnayake, B. R. S. B., 2011. Climate Change in Sri Lanka. Department of Meteorology, Colombo, Sri Lanka.

Berger, R., Weregoda, R. and Rathnabharathie, V., 2009. Participatory rice variety selection in Sri Lanka. Participatory Learning and Action, 60(1). 88-98.

Biradar, C.M., Thenkabail, P.S., Noojipady, P., Yuanjie, L., Dheeravath, V., Velpuri, M., Turral, H., Gumma, M.K., Reddy, O.G.P., Xueliang, L. C., Xiao, X., Schull, M.A., Alankara, R.D., Gunasinghe, S. and Mohideen, S., 2009. A global map of rainfed cropland areas (GMRCA) at the end of last millennium using remote sensing. International Journal of Applied Earth Observation and Geoinformation, 11. 114-129. DOI: http://dx.doi.org/10.1016/j.jag.2008.11.002.

Brown, M. E. and Funk, C.C., 2008. Food security under climate change, Science 319. 580-581. DOI: $10.1126 /$ science. 1154102 .

Bouman, B. A. M., Peng, S., Castaneda, A. R. and Visperas, R. M., 2005. Yield and water use of irrigated tropical aerobic rice systems. Agriculture Water Management, 74. 87-105. DOI: http://dx.doi.org/10.1016/j.agwat.2004.11.007.

Central Bank of Sri Lanka, (various years). Annual Report. Colombo, Sri Lanka. 
Central Bank of Sri Lanka, 2011. Sri Lanka socio-economic data-2011. Colombo, Sri Lanka.

Chandrapala, L., 1996. Long term trends of rainfall and temperature in Sri Lanka. Climate Variability and Agriculture, Y.P. Abrol, S. Gadgil and G.B. Pant (eds). Narosa Publishing House, New Delhi. 153-162.

Chhetri, N., Chaudhary, P., Tiwari, P. R. and Yadaw, R. B., 2012. Institutional and technological innovation: Understanding agricultural adaptation to climate change in Nepal. Applied Geography, 33. 142-150. DOI: http://dx.doi.org/10.1016/j.apgeog.2011.10.006.

Cline, W. R., 2007. Global Warming and Agriculture: Impact Estimates by Country. Peterson Institute for International Economics, Washington, DC.

Conway G. 2008. The science of climate change in Africa: impacts and adaptation. UK: Department of International Development.

Cruz, R.V., H. Harasawa, M. Lal, S. Wu, Y. Anokhin, B. Punsalmaa, Y. Honda, M. Jafari, C. Li and N. Huu Ninh, 2007: Asia. Climate Change 2007: Impacts, Adaptation and Vulnerability. Contribution of Working Group II to the Fourth Assessment Report of the Intergovernmental Panel on Climate Change, M. L. Parry, O. F. Canziani, J. P. Palutikof, P. J. van der Linden and C.E. Hanson(eds). Cambridge University Press, Cambridge, UK. 469506. 
De Costa, W. A. J. M., 2000. Prediction of the effects of elevated $\mathrm{CO}_{2}$ and temperature on irrigated rice yields in the low-country dry zone of Sri Lanka using a process-based simulation model. Journal of the National Science Foundation of Sri Lanka, 28. 165-84.

De Costa, W. A. J. M., Weerakoon, W. M. W., Herath, H. M. L. K. and Abeywardena, R. M. I. 2003. Response of growth and yield of rice (Oryza sativa) to elevated atmospheric carbon dioxide in the sub humid zone of Sri Lanka. Journal of Agronomy and Crop Science, 189. 83-95. DOI: 10.1046/j.1439-037X.2003.00013.x.

De Costa, W. A. J. M., Weerakoon, W. M. W., Chinthaka, K. G. R., Herath, H. M. L. K., Abeywardena, R. M. I., 2007. Genotypic Variation in the Response of Rice (Oryza sativa L.) to Increased Atmospheric Carbon Dioxide and its Physiological Basis. Journal of Agronomy and Crop Science, 193. 117-130. DOI: 10.1111/j.1439-037X.2007.00255.x.

De Costa, W. A. J. M., (2008). Climate change in Sri Lanka: myth or reality? Evidence from long-term meteorological data. Journal of the National Science Foundation of Sri Lanka, 36. 63-88.

Department of Census and Statistics, 2004. Census of Agriculture 2004. Colombo, Sri Lanka.

De Silva, C. S., 2006. Impacts of climate change on water resources in Sri Lanka. Paper for the 32nd WEDC International Conference, Colombo, Sri Lanka.

De Silva, C. S., Weatherhead, E. K., Knox, J. W. and Rodriguez-Diaz, J. A., 2007. Predicting the impacts of climate change - A case study of paddy irrigation water requirements in Sri 
Lanka. Agricultural Water Management, 93. 19-29. DOI:

http://dx.doi.org/10.1016/j.agwat.2007.06.003.

De Silva, G. J. and Sonnadara, D. U. J., 2009. Climate change in the hill country of Sri Lanka. Proceedings of the Technical Sessions, Institute of Physics, Sri Lanka.

Domroes, M., 1996. Rainfall variability over Sri Lanka. Climate Variability and Agriculture, Yash, P.A., Suloclana, G., Govind, B (eds). Narosa Publishing House: New Delhi. 163-179.

Domroes, M. and Schaefer, D., 2000. Trends of recent temperature and rainfall changes in Sri Lanka. Proceedings of the International Conference on Climate Change and Variability, T. Mikami (ed). Tokyo Metropolitan University, Japan. 197-204.

Droogers, P., 2004. Adaptation to climate change to enhance food security and preserve environmental quality: example for southern Sri Lanka. Agricultural Water Management, 66. 15-33. DOI: http://dx.doi.org/10.1016/j.agwat.2003.09.005.

Eisenack, K., Stecker, R., 2011 A framework for analyzing climate change adaptations as actions. Mitigation and Adaptation Strategies for Global Change (in press). DOI: 10.1007/s11027-011-9323-9.

Esham, M., Kobayashi, H., Usami, K. and Matsumura, I., 2005. Factors influencing crop diversification in Sri Lanka. Japanese Journal of Farm Management, 44(1).148-152. 
Esham, M. and Garforth, C., 2012. Agricultural adaptation to climate change: insights from a farming community in Sri Lanka. Mitigation and Adaptation Strategies for Global Change (in press). DOI: 10.1007/s11027-012-9374-6.

Fernando, T. K., 2000, Impact of climate change on paddy production in Sri Lanka. Global Environmental Research, 2. 169-176.

Fernando, M. T. N., Zubair, L., Peiris, T. S. G., Ranasinghe, C. S. and Ratnasiri, J., 2007. Economic Value of Climate Variability Impacts on Coconut Production in Sri Lanka. AIACC Working Paper No. 45.

Fankhauser, S., Smith J. B., Tol, R. S. J., 1999. Weathering climate change: some simple rules to guide adaptation decisions. Ecological Economics, 30. 67-78. DOI: http://dx.doi.org/10.1016/S0921-8009(98)00117-7.

Goddard, L., Mason, S. J., Zebiak, S.E., Ropelewski, C.F., Basher, R. and Cane, M. A., 2010. Current approaches to seasonal-to-interannual climate predictions. International Journal of Climatology, 21. 1111-1152. DOI: 10.1002/joc.636.

Gornall, J., Betts, R., Burke, E., Clark, R., Camp, J., Willett, K. and Wiltshire, A., 2010. Implications of climate change for agricultural productivity in the early twenty-first century. Philosophical Transactions of the Royal Society B-Biological Sciences, 365. 2973-2989. DOI: 10.1098/rstb.2010.0158. 
Halder, P., Sharma, R. and Alam, A., 2012. Local perceptions of and responses to climate change: experiences from the natural resource-dependent communities in India. Regional Environmental Change (in press). DOI:10.1007/s10113-012-0281-x.

Harris, K. D. and Shatheeswaran, T., 2005, Performance of improved four test rice entries of short duration (2.5 months) in the eastern region of Sri Lanka, Proceedings of the 61st Annual Session of Sri Lanka Association for the Advancement of Science (SLASS), Section B. Colombo, Sri Lanka. 21 p.

Herath, S. and Ratnayake, U., 2004. Monitoring rainfall trends to predict adverse impacts-a case study from Sri Lanka (1964-1993). Global Environmental Change, 14. 71-79. DOI: http://dx.doi.org/10.1016/j.gloenvcha.2003.11.009.

Imbulana, K.A.U.S., Wijesekara, N.T.S. and Neupane B.R. (eds), 2006. Sri Lanka National Water Development Report. MAI \& MD, UN-WWAP, UNESCO and University of Moratuwa, Sri Lanka, Paris and New Delhi.

IPCC (Intergovernmental Panel on Climate Change), 2007a. Fourth Assessment Report. Climate Change 2007: The Physical Science Basis, Contribution of Working Group I to the Fourth Assessment Report of the Intergovernmental Panel on Climate Change, S. Solomon, D. Qin, M. Manning, M. Marquis, K. Averyt, M. M. B. Tignor, H. L. Miller and Z. Chen (eds).Cambridge University Press, Cambridge, UK.

Intergovernmental Panel on Climate Change (IPCC), 2007b. Fourth Assessment Report. Climate change 2007: Impacts, adaptations, and vulnerability. Contribution of Working 
Group II to the Fourth Assessment Report of the Intergovernmental Panel on Climate Change, M. L. Parry, O. F. Canziani, J. P. Palutikof, P. J. van der Linden and C.E. Hanson(eds). Cambridge University Press, Cambridge, UK, Fourth Assessment Report. Cambridge University Press, Cambridge, UK.

Izaurralde, R. C., 2009. Global Climate Change and Agriculture. CRC Press: Taylor \& Francis, Boca Raton, FL.

Jayatillake, H. M. and Droogers, P., 2004. Will there be sufficient water under internal and external changes? Walawe Basin (Sri Lanka). Climate Change in Contrasting River Basins, J. C. J. H. Aerts and P. Droogers (eds), CABI, UK.

Jayatillake, H. M., Chandrapala, L., Basnayake, B. R. S. B. and Dharmaratne, G. H. P., 2005. Water Resources and Climate Change. Proceedings of the Workshop on Sri Lanka National Water Development Report, N. T. S. Wijesekera, K. A. U. S. Imbulana and B. Neupane (eds). World Water Assessment Programme (WWAP), Paris, France.

Jayawardena, S. N., Abeysekera, S. W., Gunathilaka, N. and Herath H. M. J. K., 2010. Potential for zero-tillage technique in rice and other field crop cultivation in rice-based cropping systems in the dry and intermediate zones of Sri Lanka. Proceedings of the National Conference on Water, Food Security and Climate Change in Sri Lanka, P. Weligamage, G. G. A. Godaliyadda and K. Jinapala (eds), BMICH, Colombo, Sri Lanka, 911 June 2009. International Water Management Institute (IWMI), Colombo, Sri Lanka. 6574. 
Kimball, B.A., Kobayashi, K. and Bindi, M., 2002. Responses of agricultural crops to free-air $\mathrm{CO}_{2}$ enrichment. Advances in Agronomy, 77. 293-368. DOI: http://dx.doi.org/10.1016/S0065-2113(02)77017-X.

Kudagamage, C. 1998. Present status of horticultural research in Sri Lanka. Paper for the World Conference on Horticultural Research (WCHR), 17-20 June 1998, Rome, Italy

Kumar, P., Kumar, R. K., Rajeevan, M. and Sahai, A. K., 2007. On the recent strengthening of the relationship between ENSO and north-east monsoon rainfall over South Asia. Climate Dynamics, 28(6). 649-660. DOI: 10.1007/s00382-006-0210-0.

Kurukulasuriya, P. and Ajwad, M. I., 2007. Application of the Ricardian technique to estimate the impact of climate change on smallholder farming in Sri Lanka. Climatic Change, 81. 39-59. DOI: 10.1007/s10584-005-9021-2.

Lal, M., 2003. Global climate change: India's monsoon and its variability. Journal of Environmental Studies and Policy, 6(1).1-34.

Lobell, D. B., and Field, C. B., 2007. Global scale climate-crop yield relationships and the impacts of recent warming. Environmental Research Letters, 2. 7. DOI:10.1088/17489326/2/1/014002.

Long, S. P., Ainsworth, E.A., Leakey, A.D.B., Nosberger, J. and Ort, D. R., 2006. Food for thought: lower than expected crop yield stimulation with rising $\mathrm{CO}_{2}$ concentrations. Science, 312. 1918-1921. DOI: 10.1126/science.1114722 
Malmgren, B., Hhulugalla, R., Hayashi, Y. and Mikami, T., 2003. Precipitation trends in Sri Lanka since the 1870 s and relationships to El-Nino-southern oscillation. International Journal of Climatology, 23. 1235-1252. DOI: 10.1002/joc.921.

Manandhar, S., Schmidt-Vogt, D., Perret, S.R., Kazama, F., 2011. Adapting cropping systems to climate change in Nepal: a cross-regional study of farmers' perception and practices. Regional Environmental Change, 11(2). 335-348. DOI 10.1007/s10113-010-0137-1.

Ministry of Environment in Sri Lanka, 2010, 2012. National Climate Change Adaptation for Sri Lanka 2011 to 2016. Colombo, Sri Lanka.

Ministry of Urban Development and Water Supply Sri Lanka, 2005. National Rainwater Policy and Strategies. Colombo, Sri Lanka. http://www.lankarainwater.org/rwhsl/nrwpolicy _2005.pdf [accessed on 22 November 2011].

Molen, V. P. 2001. Rains droughts and dreams of prosperity. PhD thesis University of Twente, Netherlands.

Morton, J. F., 2007. The impact of climate change on smallholder and subsistence agriculture. Proceedings of the National Academy of Sciences, 104.19680-85. DOI: 10.1073/pnas.0701855104.

Nagarajan, S., Jagadish, S.V.K., Hari Prasad, A.S., Thomar, A.K., Anand, A., Pal, M. and Aggarwal, P.K., 2010. Local climate affects growth, yield and grain quality of aromatic 
and non-aromatic rice in northwestern India. Agriculture, Ecosystem and Environment, 138. 274-281. DOI: http://dx.doi.org/10.1016/j.agee.2010.05.012.

Nainanayake, A. D. and Morison, J. I. L., 2007. A case study on physiology-based drought screening of coconut with selected accessions. Cocos, 18. 01-20.

Nianthi, R., 2010. Climate change adaptation and agroforestry in Sri Lanka. Climate Change Adaptation and Disaster Risk Reduction: An Asian Perspective (Community, Environment and Disaster Risk Management, Volume 5), R. Shaw, J. M. Pulhin, J. J. Pereira (eds). Emerald Group Publishing Limited. 285-305.

Nelson, G. C., Rosergrant, M. W., Koo, J., Robertson, R, Sulser, T., Zhu, T., Ringler, C., Msangi, S., Palazzo, A., Batka, M., Magalhaes, M., Valmonte-Santos, R., Ewing, M. and Lee, D., 2009. Climate change impact on agriculture and costs of adaptation. International Food Policy Research Institute Washington, DC.

Panabokke, C.R., 1996. Soils and Agro-ecological Environments of Sri Lanka. Natural Resources, Energy and Science Authority, Sri Lanka.

Panabokke, C. R. and Punyawardena, B. V. R., 2010, Climate change and rain-fed agriculture in the dry zone of Sri Lanka. Proceedings of the National Conference on Water, Food Security and Climate Change in Sri Lanka, A. Evans and K. Jinapala(eds), BMICH, Colombo, Sri Lanka, 9-11 June 2009. International Water Management Institute (IWMI). 141-146. 
Peiris, T. S. G., Wijeratne, M., Ranasinghe, C. S., Aanadacumaraswamy, A., Fernando, M. T. N., Jayakody, A. and Ratnasiri, J., 2004. Impact of climate change on coconut and tea industry in Sri Lanka. Paper for the 2nd AIACC Regional Workshop for Asia and the Pacific, Manila, the Philippines.

Peiris, T. S. G., Hansen, J. W. and Zubzir, L., 2008. Use of seasonal climate information to predict coconut production in Sri Lanka. International Journal of Climatology, 28. 103110. DOI: $10.1002 /$ joc. 1517.

Peng, S., Huang, J., Sheehy, J.E., Laza, R.C., Visperas, R.M., Zhong, X., Centeno, G.S., Khush, G.S. and Cassman. K.G., 2004. Rice yields decline with higher night temperature from global warming, Proceedings of the National Academy of Sciences, 101. 9971-9975. DOI:10.1073/pnas.0403720101.

Punyawardena, B. V. R., 2008. Walawe basin and Climate change: Is it a myth or reality? Paper for the Workshop on the case study in Walawe basin, 03-04 October 2008, Sri Lanka.

Ranatunge, E., Malmgren, B.A., Hayashi, Y., Mikami, T., Morishima, W., Yokozawa, M., Nishimori, M., 2003. Changes in the Southwest Monsoon mean daily rainfall intensity in Sri Lanka: relationship to the El Niño-Southern Oscillation, Palaeogeography, Palaeoclimatology, Palaeoecology, 197(1). 1-14. DOI: http://dx.doi.org/10.1016/S00310182(03)00383-3. 
Rupakumar, K. and Patil, S. D., 1996. Long-term variations of rainfall and surface air temperature over Sri Lanka. Climate Variability and Agriculture, Y. P. Abrol, S. Gadgil and G. B. Pant(eds), Narosa Publishing House, New Delhi, India. 135-152.

Senalankadhikara, S. and Manawadu, L., 2010. Rainfall fluctuation and changing patterns of agriculture practices. Proceedings of the National Conference on Water, Food Security and Climate Change in Sri Lanka, A. Evans and K. Jinapala(eds), BMICH, Colombo, Sri Lanka, 9-11 June 2009. International Water Management Institute (IWMI). 127-139.

Senaratne, A. and Wickramasinghe, K., 2010. Climate change, local institutions and adaptation experience: the village tank farming community in dry zone Sri Lanka. Proceedings of the National Conference on Water, Food Security and Climate Change in Sri Lanka, A. Evans and K. Jinapala(eds), BMICH, Colombo, Sri Lanka, 9-11 June 2009. International Water Management Institute (IWMI). 147-156.

Seo, S. N. N., Mendelsohn, R. and Munasinghe, M., 2005. Climate change and agriculture in Sri Lanka: a Ricardian valuation. Environment and Development Economics, 10. 581-96. DOI:10.1017/S1355770X05002044.

Silva, R. P., 2008. Understanding drought-implications, strategies and policies in Sri Lanka. Drought and Integrated Water Resource Management in south Asia, Sage Publication, India. 125-155.

Smith, J.B., 1997. Setting priorities for adapting to climate change. Global Environmental Change, 7(3). 251-264. DOI: http://dx.doi.org/10.1016/S0959-3780(97)00001-0. 
Smit, B., Skinner, M., 2002. Adaptation options in agriculture to climate change: a typology. Mitigation and Adaptation Strategies for Global Change, 7. 85-114.

Somaratne, W. G., 2010. The System of Rice Intensification (SRI) and food security among the poor: opportunities and constraints, Proceedings of the National Conference on Water, Food Security and Climate Change in Sri Lanka, P. Weligamage, G. G. A. Godaliyadda and K. Jinapala (eds), BMICH, Colombo, Sri Lanka, 9-11 June 2009. International Water Management Institute (IWMI), Colombo, Sri Lanka. 81-91.

Stage, J., 2010. Economic valuation of climate change adaptation in developing countries. Annals of the New York Academy of Sciences, 1185(1). 150-163.

Sterrett, C., 2011. Review of Climate Change Adaptation Practices in South Asia. Oxfam Research Report.

Sumanaratne, B.M., 2011. Public expenditure reforms and rural poverty in Sri Lanka. Sri Lanka Journal of Advanced Social Studies, 1(1). 101-144.

Suppiah, R., 1997. Extremes of the southern oscillation phenomenon and the rainfall of Sri Lanka. International Journal of Climatology, 17(1). 87-101. DOI: 10.1002/(SICI)10970088(199701)17:1<87::AID-JOC95>3.0.CO;2-X.

Tol, R. S. J., 2005. Adaptation and mitigation: trade-offs in substance and methods. Environmental Science \& Policy, 8. 572-578. DOI:10.1016/j.envsci.2005.06.011. 
Welch, J. R., Vincent, J. R., Auffhammer, M., Moya, P. F., Dobermann, A. and Dawe, D., 2010. Rice yields in tropical/subtropical Asia exhibit large but opposing sensitivities to minimum and maximum temperatures. Proceedings of the National Academy of Sciences, 107. 14562-14567. DOI: 10.1073/pnas. 1001222107.

Wijeratne, M. A., 1996. Vulnerability of Sri Lanka tea production to global climate change. Water, Air and Soil Pollution, 92. 87-94. DOI: 10.1007/BF00175555.

Wijeratne, M. A., and Fordham, R., 1996. Effect of environmental factors on growth and yield of tea (Camellia sinensis L.) in the low country wet zone of Sri Lanka. Sri Lankan Journal of Tea Science, 46. 21-34.

Wijeratne, M. A., Anandacoomaraswamy, A., Amaratunge, M. K. S. L. D., Ratnasiri, J., Basnayake, B. R. S. B. and Kalra, N., 2007. Assessment of impact of climate change on productivity of tea (camellia sinensis 1.) plantations in Sri Lanka. Journal of the National Science Foundation of Sri Lanka, 35. 119-126.

World Bank, 2008. Agriculture for development, Washington DC, USA: World Bank.

Zubair, L., 2002. El-Niño-Southern Oscillation influences on rice production in Sri Lanka. International Journal of Climatology, 22. 242- 250. DOI: 10.1002/joc.714.

Zubair, L. and Ropelewski, C. F., 2006. The strengthening relationship between ENSO and north-east monsoon rainfall over Sri Lanka and Southern India. Journal of Climate, 19. 1567-1575. DOI:http://dx.doi.org/10.1175/JCLI3670.1. 
Zubair, L., Siriwardhana, M., Chandimala, J. and Yahiya, Z., 2008, Predictability of Sri Lankan rainfall based on ENSO. International Journal of Climatology, 28. 91-101. DOI: 10.1002/joc. 1514

Zubair, L., Hansen, J., Yahiya, Z., Siriwardhana, M., Chandimala, J., Razick, S., Tennakoon, U., Ariyaratne, K., Bandara, I., Bulathsinhala, H., Abeyratne, T. and. Samuel, T. D. M. A., 2010. Impact Assessment and Adaptation to Climate Change of Plantations in Sri Lanka. IRI Technical Report. 
TABLE 1 Agricultural adaptation to climate change

\begin{tabular}{|c|c|c|}
\hline Category of adaptation & Example and description & Source \\
\hline \multirow[t]{3}{*}{ Government programs } & Ratification of the UNFCC in 1993 and the Kyoto protocol in 2002 & Ministry of Environment, Sri \\
\hline & $\begin{array}{l}\text { Drafting of the National Climate Change Adaptation Strategy (NCCAS)- NCCAS is structured into the following five } \\
\text { strategic thrusts; mainstream CCA into national planning and development, enable climate resilient and healthy human } \\
\text { settlements, minimize CC impacts on food security, improve climate resilience of key economic drivers and safeguard } \\
\text { natural resources and biodiversity from CC impacts }\end{array}$ & $\begin{array}{l}\text { Ministry of Environment, Sri } \\
\text { Lanka (2010) }\end{array}$ \\
\hline & Implementation of National Rainwater Harvesting Policy & $\begin{array}{l}\text { Ministry of Urban } \\
\text { Development and Water } \\
\text { Supply (2005) }\end{array}$ \\
\hline \multirow[t]{5}{*}{$\begin{array}{l}\text { Technological } \\
\text { development }\end{array}$} & $\begin{array}{l}\text { Development of short duration rice varieties- varieties suitable for shorter growing seasons have been developed and } \\
\text { tested in the Eastern province }\end{array}$ & $\begin{array}{l}\text { Harris and Satheeswaran } \\
\text { (2005) }\end{array}$ \\
\hline & $\begin{array}{l}\text { Identification of rice varieties suitable for high } \mathrm{CO}_{2} \text { concentration at Rice Research and Development Institute in Sri } \\
\text { Lanka }\end{array}$ & De Costa et al. (2007) \\
\hline & $\begin{array}{l}\text { Development of drought resistant coconut varieties and salt tolerant rice varieties by research institutes at the Coconut } \\
\text { Research Institute }\end{array}$ & $\begin{array}{l}\text { Nainanayake and Morison } \\
\text { (2007) }\end{array}$ \\
\hline & Indigenous weather forecasting - using meteorological indicators and animal behaviour to predict the weather & $\begin{array}{l}\text { UNFCC database on local } \\
\text { coping strategies }\end{array}$ \\
\hline & $\begin{array}{l}\text { Participatory research to identify salt tolerant rice varieties - a project involving participatory research as an approach } \\
\text { to multi-stakeholder involvement in the reintroduction of indigenous saline tolerant rice varieties suitable for local } \\
\text { conditions in the Hambantotta district }\end{array}$ & $\begin{array}{l}\text { Berger et al. (2009) } \\
\text { Sterrett (2011) }\end{array}$ \\
\hline \multirow[t]{3}{*}{$\begin{array}{l}\text { Farm production } \\
\text { practices }\end{array}$} & $\begin{array}{l}\text { Adjustment of farm practices in line with rainfall pattern, using rainwater stored in the community owned village tanks } \\
\text { and ground water use in the Anuradhapura district }\end{array}$ & $\begin{array}{l}\text { Senartne and } \\
\text { Wickramasinghe (2010) }\end{array}$ \\
\hline & Adoption of crop management, land management and irrigation management practices in the Ratnapura district & Esham and Garforth (2012) \\
\hline & $\begin{array}{l}\text { New Kekulam rice cultivation practice - a rice cultivation practice involving land preparation with zero tillage in the } \\
\text { dry and intermediate zones }\end{array}$ & $\begin{array}{l}\text { Jayewardene et al (2010) } \\
\text { UNFCC database on local } \\
\text { coping strategies }\end{array}$ \\
\hline
\end{tabular}


Traditional work(Pangu) distribution practice- a system of sharing the work for cleaning and maintaining small-scale irrigation systems in the dry zone

Molen (2001)

UNFCC database on local

coping strategies

Practice of agro forestry where tree species are cultivate along with agricultural crops. Practised in all agro climatic

Nianthi(2009) 


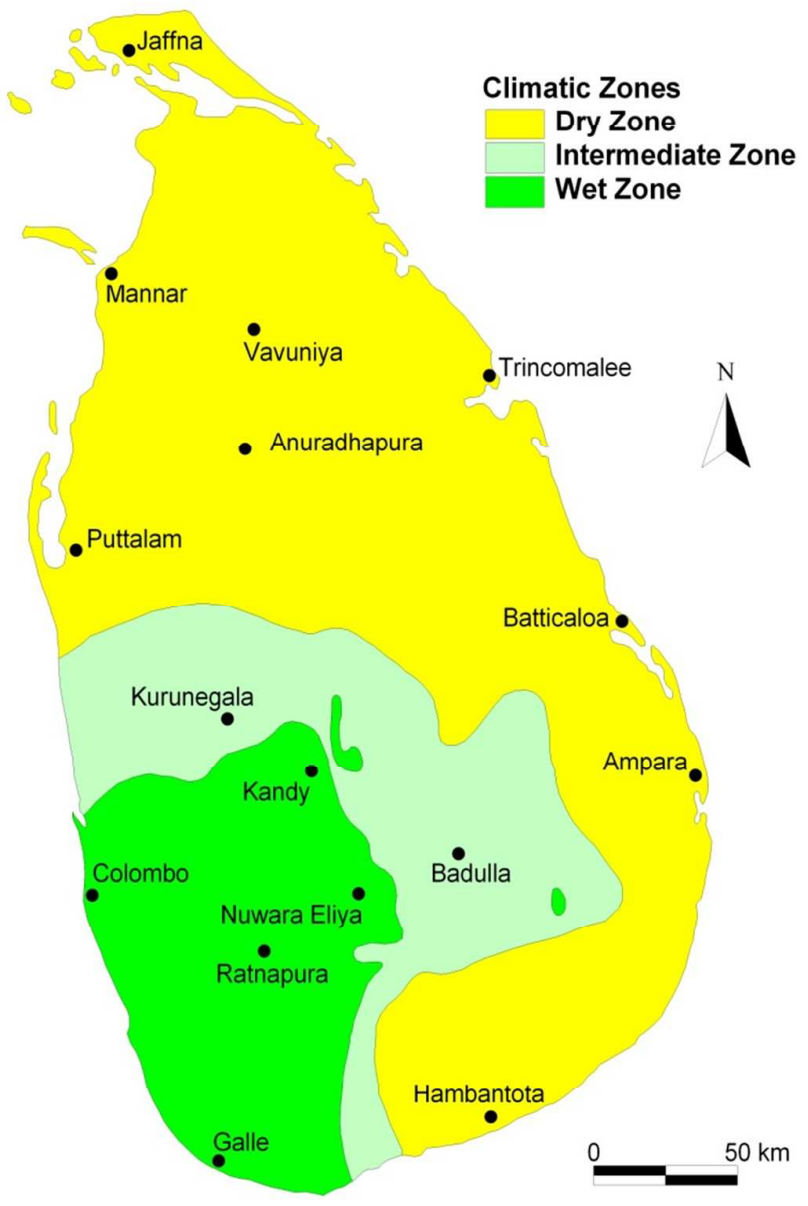

FIGURE 1 Main agro-climatic zones in Sri Lanka 


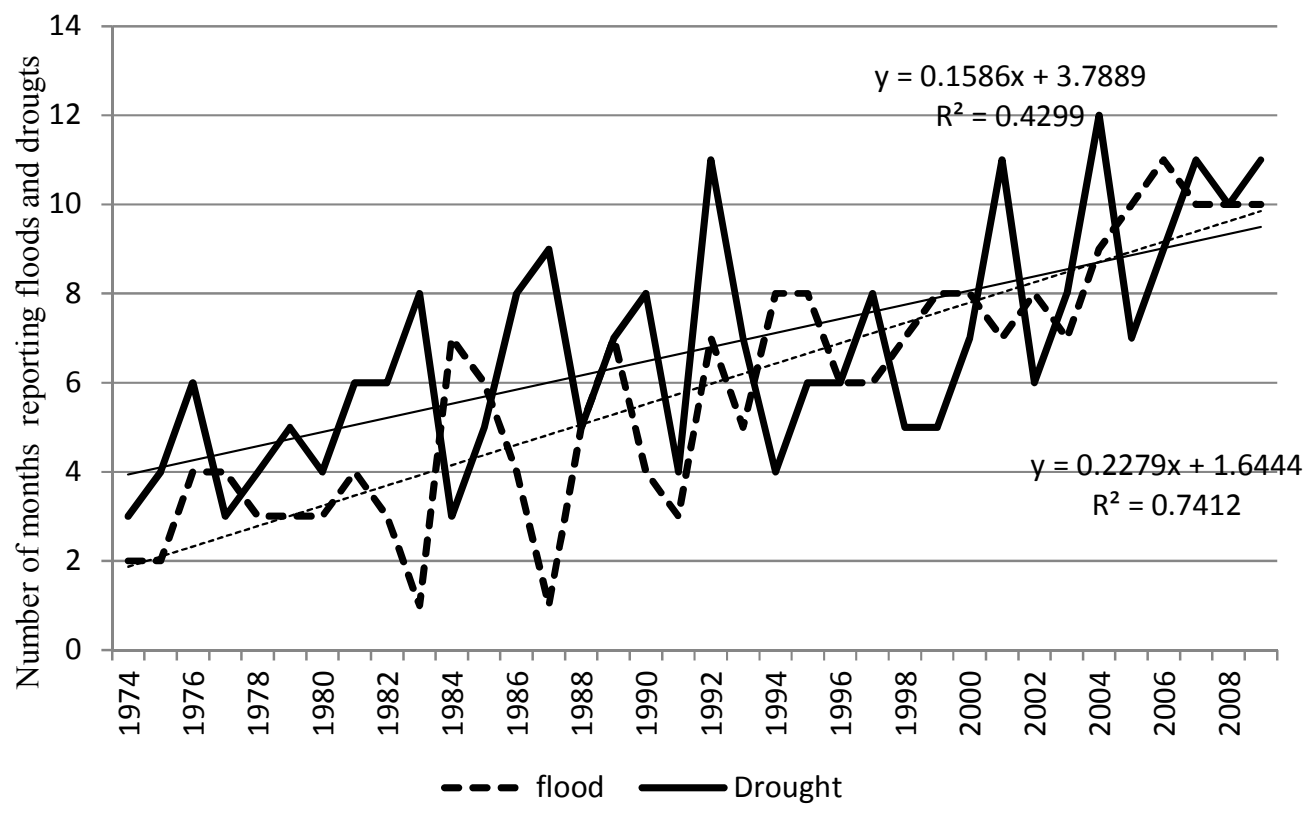

Data source: Disaster Management Centre, Sri Lanka

FIGURE 2 Trends of flood and drought frequency 


\section{Climate change and agricultural adaptation in Sri Lanka: a review}

\section{Response to the reviewer 2 (Responses in italics)}

\section{Comment}

My only concern is that the authors review climate change in Sri Lanka in total isolation from the broader context without considering similar trends throughout South Asia. It would be useful to include a section making connection the broader geographic context.

\section{Responses}

Following paragraph was added to section 2.2.1 (marked red in the manuscript)

Surface air temperature and precipitation are two key climatic variables that influence the agricultural sector in South Asia. Past and present climate trends and variability in South Asia are characterised by increasing surface air temperature. The analysis of seasonal and annual surface air temperatures for a number of locations in South Asia has revealed a significant warming trend of $0.7^{\circ} \mathrm{C}$ per century (Lal, 2003). During recent decades, the observed increases in some parts of South Asia such as India, Bangladesh, Nepal, Pakistan and Sri Lanka have ranged between $0.07-1^{\circ} \mathrm{C}$ per decade (Cruz et al., 2007). Although some parts of South Asia recorded increasing and decreasing trends in the seasonal rainfall, in general, the rainfall fluctuations in South Asia have been largely random over the years, with no clear trend in the rainfall pattern (Cruz et al., 2007).

Following sentence was added to section 2.2.2, under subtitle rainfall (marked red in the manuscript)

Climate models indicate an increase in annual rainfall in most of Asia during this century, while the summer monsoon is projected to produce more rainfall over South Asia (Cruz et al., 2007). 


\section{Note}

Please note that in Section 2.2.2, under subtitle temperature reference was made to South Asian context as follow:

The IPCC predicts that South Asia will experience warming above the global average. By the end of the 21st century, the mean temperature in South Asia is projected to increase by $3.3^{\circ} \mathrm{C}$ (IPCC, 2007a). 